tolento

\title{
Utilization of Moringa (Moringa Oleifera) as A Multi Function Plant for Conservation Land in Lumban Suhi-Suhi Village, Samosir Regency
}

\author{
Nurzainah Ginting ${ }^{1 *}$, Nurlisa Ginting ${ }^{2}$, Dwira Nirfalini Aulia ${ }^{3}$, Juliza \\ Hidayati $^{4}$, KK-PKDT\&PB ${ }^{5}$ \\ ${ }^{1,5}$ Program Study of Animal Production, Faculty of Agriculture, Universitas Sumatera Utara \\ ${ }^{2,5}$ Program Study of Architecture, Faculty of Engineering, Universitas Sumatera Utara \\ ${ }^{3,5}$ Program Study of Architecture, Faculty of Engineering, Universitas Sumatera Utara \\ ${ }^{4,5}$ Department of Industrial Engeneering, Faculty of Engineering, Universitas Sumatera Utara \\ ${ }^{5}$ KK-PKDT\&PB:Kelompok Kerja Parawisata Kawasan Danau Toba dan Parawisata Berkelanjutan USU
}

\begin{abstract}
Toba Water Catchment Area (WCA) is approximately 369,854 ha, consists of about $65 \%$ land and $35 \%$ water. In Lake Toba WCA there is a land area of 235. 217 $\mathrm{ha}(61.23 \%)$ is classified as critical and if it is not conserved will have a major impact on WCA quality. The criticality of the land around WCA Lake Toba gives a significant impact on the aesthetic side of WCA Lake Toba.The village of Lumban Suhi-suhi located in Samosir Regency is one of the tourist destination and found quite a lot of locations with the habitat of Imperata which an indicator of critical land. Local people maintains many endemic goats namely Goat Panorusan Samosir that require good quality feed.Moringa (Moringa oleifera) is a multi-functional plant, as the Moringa (Moringa oleifera) plant has a root nodule that captures $\mathrm{N}$ from the air and stores it on the root so Moringa can help fertilize the soil.This dedication has been done in October 2017 in Lumban Suhi-suhi Village, Samosir and the objectives is to train the community to cultivate the Moringa plant (Moringa oleifera). The output of this dedication are the community do conservation by planting Moringa so that Lumban Suhi-suhi village and its surrounding turns green and fertile and there will be available good quality goat feed. It is also expected that Lumban Suhi-suhi village becomes a tourist village that attracts more tourists.
\end{abstract}

Keywords: Moringa (Moringa oleifera), Conservation, Lumban Suhi-suhi, Tourism

Abstrak. Daerah Tangkapan Air (DTA) Danau Toba seluas lebih kurang 369.854 Ha, sekitar 65\% berupa daratan dan $35 \%$ berupa perairan. Di DTA Danau Toba terdapat lahan seluas 235.217 Ha (61,23\%) tergolong kritis dan apabila dibiarkan 
akan membawa pengaruh besar terhadap kualitas DTA. Kekritisan lahan-lahan di sekitar DTA Danau Toba memberikan dampak yang siknifikan terhadap sisi estetika DTA Danau Toba. Desa Lumban Suhi-suhi terletak di Kabupaten Samosir merupakan salah satu dewa wisata dan ditemukan cukup banyak lokasi dengan habitat alang-alang yang tergolong lahan kritis. Masyarakat banyak memelihara kambing endemik yaitu Kambing Panorusan Samosir yang memerlukan pakan yang berkualitas.Tanaman Kelor (Moringa oleifera) merupakan tanaman multi fungsi, sebagai tanaman kacangan Kelor (Moringa oleifera) mempunyai bintil akar yang mampu menangkap $N$ dari udara dan menyimpannya pada bintil akar sehingga dapat membantu menyuburkan tanah. Pengabdian ini telah dilaksanakan pada bulan Oktober 2017 di Desa Lumban Suhi-suhi, Samosir bertujuan untuk melatih masyarakat membudidayakan tanaman Kelor (Moringa oleifera). Output dari pengabdian ini adalah masyarakat melakukan konservasi dengan menanam kelorsehingga Desa Lumban Suhi-suhi berubah menjadi hijau dan subur serta tersedia pakan ternak kambing berkualitas. Diharapkan juga Desa Lumban Suhi-suhi menjadi desa wisata yang menarik lebih banyak wisatawan.

Kata Kunci: Kelor (Moringa oleifera), Konservasi, Lumban Suhi Suhi, Wisata Received 20 September 2018 |Revised 30 November 2018|Accepted 30 January 2019

\section{Introduction}

Samosir Regency consists of 9 districts; 6 sub-districts are located in Samosir Island, and other 3 sub-districts in the outer ring area of Lake Toba, which are right on the ridge of the Bukit Barisan mountain range. The regency has an area of $1419.5 \mathrm{~km}^{2}$ with a population density of 105 people / km² [1], making Samosir Regency one of the largest mountain craters in the world where humans live. In 2017 Lake Toba was choosen by Indonesia Government as one of international tourist destination. Associated with this, a research has conducted by World Bank Group [2] and the result mentioned that a sustainable tourism management has to be implemented in order to preserve the environment. In addition, Kementrian Pekerjaan Umum dan Perumahan Rakyat Badan Pengembangan Infrastruktur Wilayah Program Pembangunan Pariwisata Indonesia [3] mentioned that any policy regards with developing an area as tourist destination so a good management on environment should be taken. By doing this, both tourism and environment will have a good output.

Geographically, Samosir Regency is situated on 2024 '- 20 25' North Latitude and 980 21 '- 99055 BT'. Administratively, the Samosir Regency area is bordered by seven districts. In the north side are Karo Regency and Simalungun Regency. In the east line is Toba Samosir Regency. In the south edge are North Tapanuli Regency and Humbang 
Hasundutan Regency. In the west area are Dairi Regency and Pak Pak Barat Regency. Topographic soil types and soil contours in Samosir Regency are generally hilly and bumpy ground [4].

Lumban Suhi-suhi village is located in Pangururan Subdistrict, consisting of 3 villages (Dusun) namely: Dusun 1, Dusun 2, and Dusun 3 [5]. The villageshave plenty of tourist objects, such as Pasir Putih Beach, traditional houses, weaving activities and coffee plantations which have a beautiful view because it spreads to the mountains. Although it has been designated astourist villages, reeds (alang-alang), an indicator of critical land are also found in many places. Therefore, a conservation effort is needed to repair the critical land. One of the most practical ways is to plant the land with multi-functional plants, such as Moringa (Moringa oleifera).

Moringa is a legume tree that can increase soil fertility because it has root nodules. Moringa has aesthetic values to the environment because it grows very quick, grows shady if it is diligently trimmed and fresh green in colour. In addition Moringa is the best selection for conservation plants in Lumban Suhi-suhi village, because Moringa prunning is very good for animal feeds as many people have goats, buffalos and cattles. Moreover, from observations in the field, Moringa is one of the plants that has high palatability for goats and buffaloes. Moringa is also good for human consumption, as the nutrients contained in Moringa cause this plant to be consumed as a source of protein. Moringa also contains active ingredients to help overcome diabetes so that the Moringa leaves has the useful prospect in producing Moringa tea.

Based on the situation analysis, it is expected that the utilizaton of Moringa (Moringa oleifera) as multi function plants can be a solution for conservation in Lumban Suhi-suhi Village, Samosir District". The Moringa planting have other benefits including improving thecritical lands in Lumban Suhi-Suhi Village. In this service, prospective trainers will also be formed, so that they can carry out further training related to the conservation. The target of this service activity is the people of Lumban Suhi-suhi Village, Pangururan District, Samosir Regency. The expected output from this community service activity arethe critical land is conserved, the villages will become greener, goat and buffalo feeds will be available, along with the community will be healthier. Future expectations arethe community produces Moringa tea and the numberof tourists will increase. 


\section{Method}

The approach taken to overcome partner problems after a comprehensive need assessment formulated in the activity plan. The approach has been taken through the application of science and technology, that was held by university to the community. The methods arecounseling, education and training in order local people can produce Moringa plant and Moringa tea. This approach is expectedto increase productivity and improve conditions faced by partners (Figure 1).

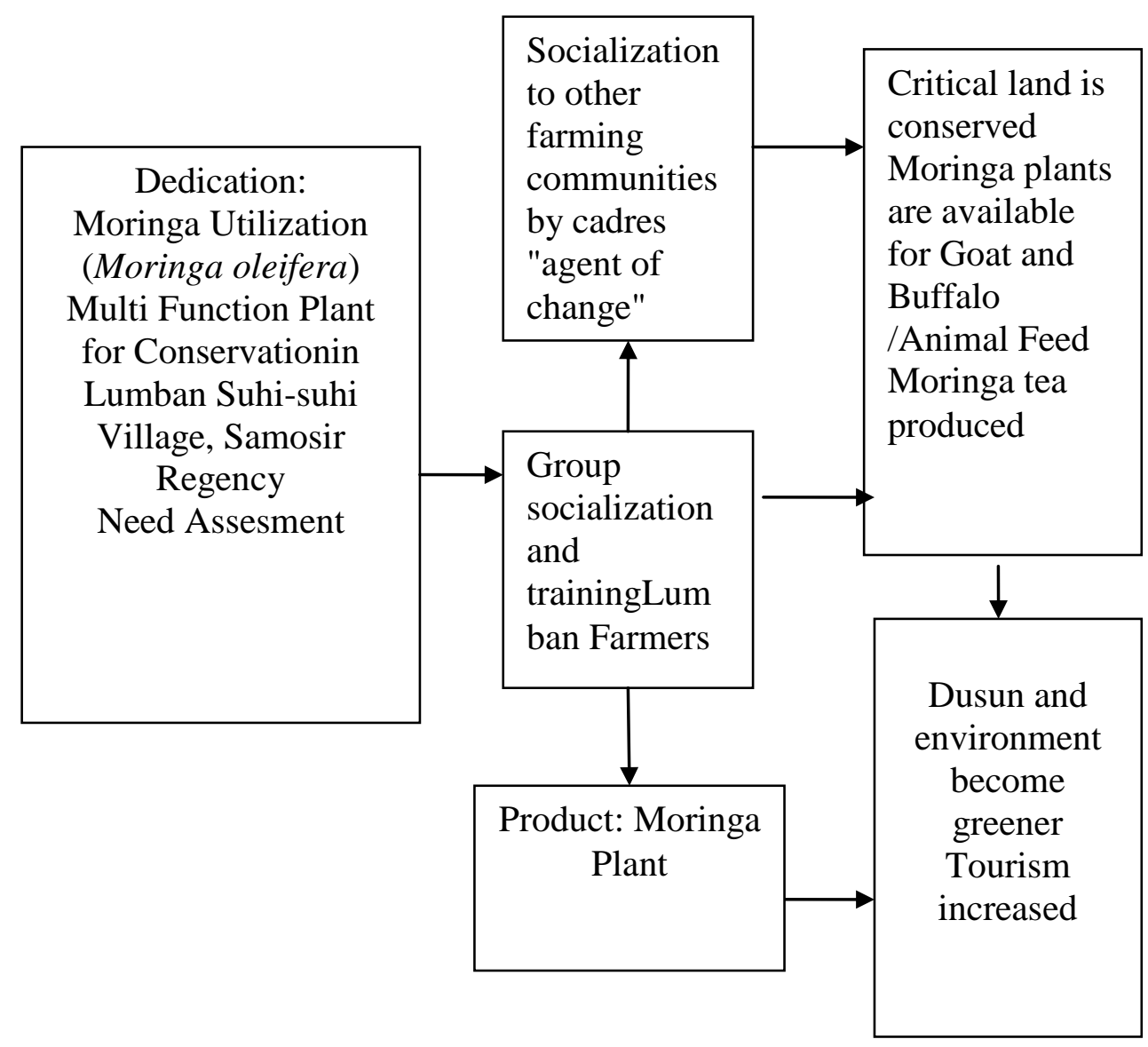

Figure 1. Approach Method Scheme

\section{Result and Discussion}

Community service activities have been carried out in the Lumban farmer group in Pangururan District, Samosir Regency. Based on the description of priority issues that have been raised, the activities that was carried out include aspects of problem solving:

\section{Technique for seedling of Moringa plants both seed and stand}

Moringa oleifera is a type of tropical plant which is easily to grow in tropical regions like Indonesia. Moringa plants are shrubs with a height of 7-11 meters and suitable grown in the lowlands area to an altitude of $700 \mathrm{~m}$ above sea level. Moringa can be 
cultivated in both tropics and subtropics in all soil types and is resistant to drought with a tolerance to drought for up to 6 months [6].

The taproot is white, enlarged like a radish. Propagation can be done either by generative (seed) or vegetative (stem cuttings) methods. Moriga usually are planted as boundaries or fences in the yard or lading in villages [7]. Moringa leaves are often used as animal feed for sheep, goats, cows, buffaloes, rabbits and are suitable for feeding cultivated fish such as gourami. The bark, leaves and roots have a very sharp and pungent odor, which can also be used to stimulate or improve digestion [8]. Another advantage of this plant has the ability to adapt to a good environment by it can grow young and fast even with plant propagation with stem or seed cuttings so that the distribution is easier. Tolerance to variations in soil types and rainfall conditions causes these plants to grow easily.

\section{Growing Terms}

Moringa oleifera grow and develop in India and Indonesia and other tropical regions of the world. As legume plants, Moringa oleiferais good to be intercorporated with other plants because they can add nitrogen. Moringa oleifera is very easy to grow either by using cuttings or seeds. Planting with cuttings is the most common practice carried out in accordance with its function as a land boundary, live fence or trellis. Cutting propagation tends to provide more biomass production because plants tend to produce many lush branches while seed propagation causes plants to tend to grow upward with the main stem and little branching.

Training with Moringa seed (Figure 2) and cuttings has been carried out. Prepared polybags and seedlings and cuttings. The planting medium is also taught, namely a combination of rice husk, buffalo manure and soil with a balanced ratio. After the polybag is filled, then the polybag is watered and then placed in the middle of a polybag, one seed or one stem. Furthermore, polybags are placed under the shade so as not to dehydrate. The community is very enthusiastic in listening to training and practice (Figure 3). 


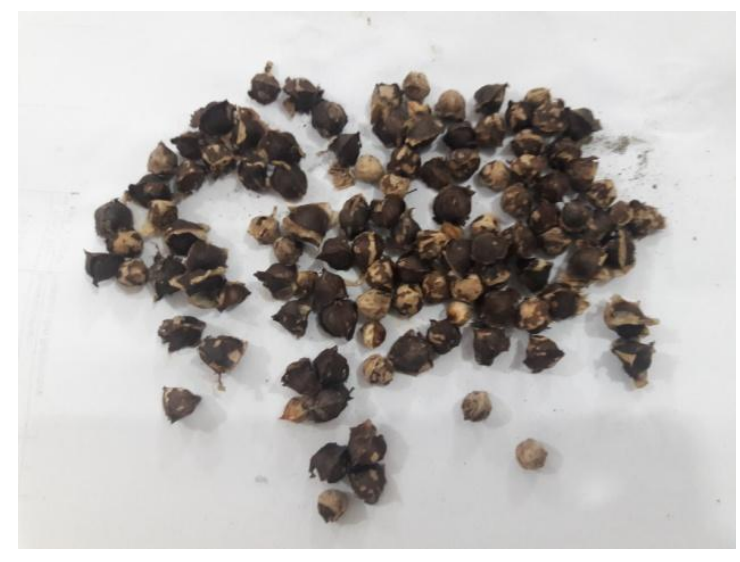

Figure 2. Moringa seed

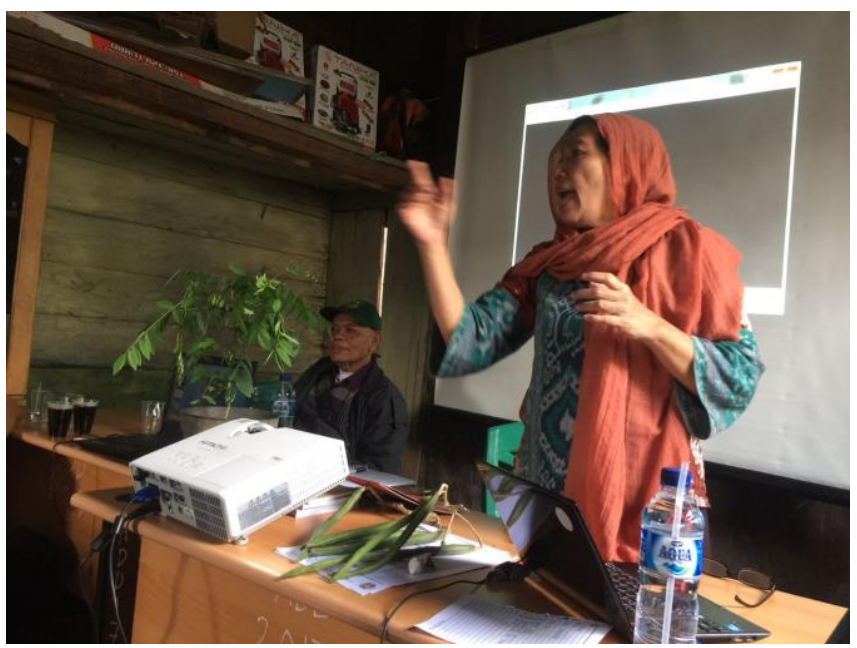

Figure 3. Training of Moringa as multi purposes plant

\section{Seed maintenance management and training transfer moringa plant to field}

Seed maintenance was conducted by cleaning polybags from weeds and watering (Figure 4). Watering was done every three days because the seedlings should not be too moist. Maintenance was carried out by the Lumban farmer group. Besides that, the seed was protected by paranet around so that it was not disturbed by livestock such as chicken and samosir goats. Seed than grew into sprout and then into Moringa plant.

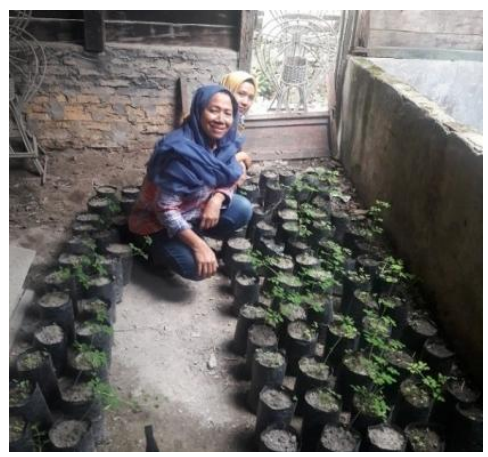

Figure 4. Moringa seed maintenance 


\section{Training of transfer moringa plant tofield}

Moringa plants were brought to field. The community were taught how to make a hole, i.e, the soil was perforated $10 \mathrm{~cm}$ first and the soil was placed separately because the soil was top soil. The hole was continued dig $10 \mathrm{~cm}$ and then the plant was inserted by cutting the polybag first and then covered by the top soil (Figure 5). All the time of planting, plant should not have too much shaking. Next, it was given shade by using leaves on the right and left.

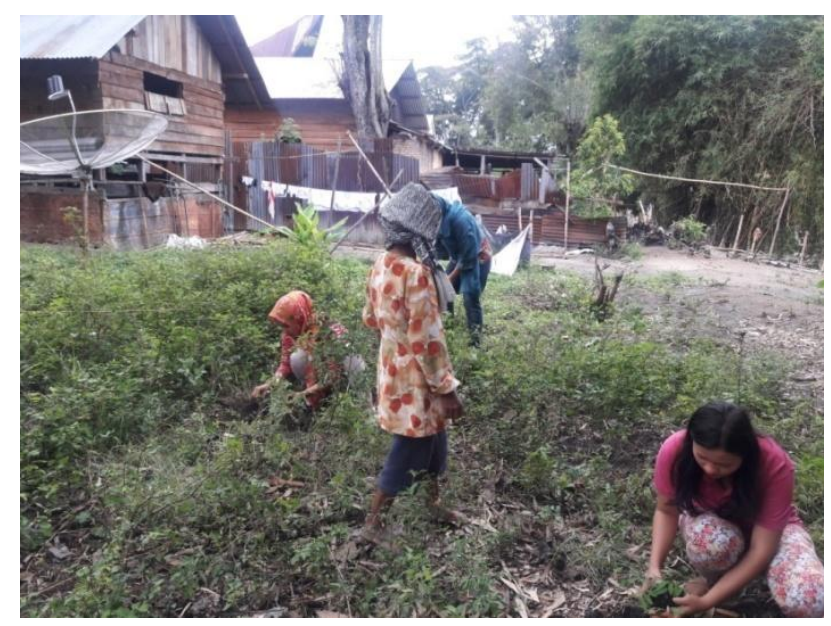

Figure 5. Growing moringa plant was planted in field

\section{Monitoring Activities}

Monitoring was carried out through phone communication to farmer groups to observethe condition of Moringa plant in the field. It was found that there were no problems with the plantations planted in the field and it grew well. It is expected that the Lumban group will be consistent in caring for the Moringa plant in the field to ensure the plants are alive. Planting for conservation should pay greater attention to its growth. Therefore, the examination process must be carried out more intensively by the community.

\section{Conclusion}

1. Moringa nurseries can be carried out since seedling until plant,

2. Adaptive Moringa plants to climatology on Samosir Island, the evidence was seed grows well and sprout appeared after one week,

3. The Lumban farmer group was enthusiastic in participating on Moringa training,

4. Monitoring has been carried out and still be continued to ensure the Moringa plant are growing well. 


\section{Acknowledgement}

The authors gratefully acknowledge that the present dedication was supported by Universitas Sumatera Utara. The support was under the grant number 106/UN5.1.R/SK/KPM/2017 for Sustainable Tourism Working Group of Universitas Sumatera Utara.

\section{References}

[1] Statistics of Sumatera Utara, 2018. Total Area, Number of Population and Population Density by Regency/City, 2015. https://sumut.bps.go.id/statictable/2016/05/19/500/luas-wilayah-jumlah-penduduk -dan-kepadatan-penduduk-menurut-kabupaten-kota-2015.html. Accessed on : 12 October 2018.

[2] World Bank Group. 2017. Indonesia: Program Pembangunan Pariwisata. Kajian Sistim Pengamanan Lingkngan dan Sosial. Wilayah Lombok, Borobudur dan Danau Toba.

[3] Kementerian Pekerjaan mum dan Perumahan Rakyat. Badan Pengembangan Infrastruktur Wilayah Program Pembangunan Pariwisata Indonesia, 2017. Komponen Bantuan Teknis. Kerangka Pengelolaan Lingkungan Dan Sosial.

[4] Samosir Statistic, 2016.

[5] Pangururan Sub District Statistic, 2015.

[6] Mendieta-Araica, B., Spörndly, E., Reyes-Sánchez, N., Salmerón-Miranda, F., and Halling, M. 2013. Biomass production and chemical composition of Moringa oleifera under different planting densities and levels of nitrogen fertilization. Agroforest. Syst. 87:81-92.

[7] Anwar, F., Latir, S., Ashraf, M., and Gilan, A. 2007. Moringa oleifera a food plant with multiple medicinal uses. Phytother. Res. 21: 17-25.

[8] Sarjono, H. T. 2008. Efek Penggunaan Tepung Daun Kelor (Moringa oleifera,Lam) Dalam Pakan Terhadap Persentase Karkas, Persentase DeposisiDaging Dada, Persentase Lemak Abdominal Dan Kolesterol Daging Ayam Pedaging. Fakultas Bioteknologi. Universitas Atma JayaYogyakarta. 